\title{
Effect of Plant Roots on Soil Nutrient Distributions in Shanghai Urban Landscapes
}

\author{
Jing Liang, Hailan Fang*, Guanjun Hao \\ Shanghai Academy of Landscape Architecture Science and Planning, Shanghai, China \\ Email: ${ }^{*}$ fhl_1969@126.com
}

Received 5 January 2016; accepted 19 February 2016; published 22 February 2016

Copyright (C) 2016 by authors and Scientific Research Publishing Inc.

This work is licensed under the Creative Commons Attribution International License (CC BY). http://creativecommons.org/licenses/by/4.0/

(c) (i)

\begin{abstract}
Twenty-seven surface soil samples were collected from four landscape sites in Shanghai, and seven soil profile samples were gathered from the two older sites for evaluation of horizontal and vertical distribution of soil properties to reveal their relationship with plant roots. Results indicated that urban soil had significant heterogeneities. Soil total nitrogen was significantly correlated with organic matter and total potassium was more abundant than total phosphorus. The available contents of iron, manganese, zinc and copper were higher than the standards for plant growth established by Soltanpour. pH and electrical conductivity increased with increasing soil vertical depth, possibly due to leaching, while the nutrients limiting plant growth such as nitrogen, phosphorus, potassium, iron, copper and zinc had more shallow distributions due to absorption by plant roots. However, with the increasing of soil depth, contents of magnesium, sodium, sulfur and chloride increased due to leaching and bio-cycling, which was further shown by the correlation analysis.
\end{abstract}

\section{Keywords}

Soil, Nutrient Element, Distribution, Leaching, Bio-Cycling

\section{Introduction}

Urban soils are the basis of landscape planting and have a great effect on plant growth. Without desirable concentrations of appropriate nutrients, plant growth is adversely affected. Moreover, since urban landscape soils are generally recognized as being highly disturbed and heterogeneous, many soils have systematic patterns and obviously differ, even in the same area. Therefore, many studies have been conducted on the physical and chemical properties of urban green space soils in major cities of China [1]. Lu et al. claimed that urban green

${ }^{*}$ Corresponding author.

How to cite this paper: Liang, J., Fang, H.L. and Hao, G.J. (2016) Effect of Plant Roots on Soil Nutrient Distributions in Shanghai Urban Landscapes. American Journal of Plant Sciences, 7, 296-305. http://dx.doi.org/10.4236/ajps.2016.72029 
space soils in Shenzhen had characteristics of sandy loam and light loam soil texture, high bulk density, low porosity and low cation exchange capacity [2]. Soil in Hong Kong had poor structure and fertility [3]. Bian et al. showed that nutrients of urban park soils were highly heterogeneous in Shenyang [4]. Degradation of soil structure and nutrient deficiency in green spaces occurred in Chongqing [5]. However, these studies mainly focused on soil macro-nutrient elements. Micro-nutrients and secondary elements are normally required in minute quantities to ensure normal plant growth and formation of flowers because they are mostly associated with the enzymatic system of plants [6]. Furthermore, the total levels of nutrients are poor indicators of their actual bioavailability to plants. The available state of elements including macro-nutrient, secondary and micro-nutrient elements is a more valuable indicator to sustain and support plant growth.

There have been numerous studies on horizontal or vertical distribution of soil nutrients; however, traditional sampling methods with fixed interval depths of 20 or $10 \mathrm{~cm}$ have generally been applied to test vertical distribution of soil physical and chemical properties, which did not conform to the distribution of plant roots and ignored soil between the sampling positions. Consequently any correlation between plant roots and soil nutrients could not be accurately determined [7]. As the underground organ of terrestrial plants, roots are indispensable for plant survival. Root systems hold the plant upright and absorb water and nutrition for plant growth and development [8]. Unfortunately, there have been very few studies on the relationship between bio-available elements and plant growth, especially the relationships between soil properties and plant roots.

Soil-amending and soil fertility practices such as plant cover systems and organic and inorganic inputs strongly influence all soil components [9]. Optimal soil properties for plant growth vary for various urban landscape species. Therefore, in this paper, four typical green areas in Shanghai-Zhongshan Park, Expo Park, Century Park and Chenshan Botanical Garden—built in different years and located in different areas were selected as sampling zones to study the distribution of soil pH, EC, CI, organic matter (OM), total nitrogen (TN), available phosphorus $(\mathrm{P})$, available potassium (K), available iron (Fe), available manganese (Mn), available zinc (Zn), available copper $(\mathrm{Cu})$, available magnesium $(\mathrm{Mg})$, available sodium $(\mathrm{Na})$ and available sulfur (S). Soil sampling depth was targeted according to the distribution of plant roots within the sampling location, to study the horizontal distribution of soil nutrients in different parks, to discuss the mechanisms of vertical distribution of soil nutrients and to evaluate the effects of soil properties on plant growth.

\section{Materials and Method}

\subsection{Study Area}

Shanghai is located at $121^{\circ} 29^{\prime}$ and $\mathrm{E} 31^{\circ} 41^{\prime} \mathrm{N}$, in the east of China, and has a total area of about $6341 \mathrm{~km}^{2}$. Shanghai is one of the most important cultural, commercial, financial, industrial and communication centers in China. The investigation areas included Zhongshan Park, Expo Park, Century Park and Chenshan Botanical Garden. Zhongshan Park was built in 1914 in Changning District with a total area of over 21.42 ha, half of which is for landscape planting. EXPO Park is green land in the city center and was built in 2010. Century Park is the biggest urban park in the inner ring road of Shanghai, situated in Pudong new district and built in 1997. Chenshan Botanical Garden, built in 2007 in Songjiang district, has a total area of 207 ha and highly diverse plant species.

\subsection{Sampling and Analysis}

Soil samples were collected from the four parks on 19-21 April 2011. Sampling depth was according to the distribution of plant roots of the sampling location. Three to four depths were sampled for arbor trees, large and medium shrubs based on the distribution of number of plant roots. Each soil sample consisted of five sub-samples which were collected from the surrounding area of each site. A total of 27 surface soil samples were collected: nine samples from Zhongshan Park, five from EXPO Park, nine from Century Park and four from Chenshan Botanical Garden. In addition, a soil profile was excavated in Zhongshan Park and Century Park. Soil samples were gathered from the profile according to the distribution of plant roots, and total of seven soil samples were collected. Details of the sampling record are presented in Table 1.

The samples were taken to the laboratory, dried at ambient room temperature and ground to pass a 2-mm sieve before analysis. Half of each sieved soil sample was further ground to pass through a 1-mm mesh screen for the determination of soil moisture coefficient, and others were passed through a 0.149 -mm mesh and stored 
Table 1. Detailed sampling record.

\begin{tabular}{|c|c|c|c|}
\hline Zones & $\begin{array}{l}\text { Number of surface } \\
\text { soil samples }\end{array}$ & $\begin{array}{l}\text { Profile soil samples } \\
\text { (distribution of plant roots) }\end{array}$ & Plants \\
\hline Zhongshan Park & 9 & $\begin{array}{c}0-18 \mathrm{~cm} \text { (developed root system) } \\
18 \text { - } 28 \mathrm{~cm} \text { (lots of roots) } \\
28 \text { - } 52 \mathrm{~cm} \text { (a few roots) } \\
52-94 \mathrm{~cm} \text { (dead roots) }\end{array}$ & $\begin{array}{l}\text { Pittosporum, Cedar, Cinnamomun } \\
\text { camphora, Ligustrum lucidum, } \\
\text { Cherry tree, Elaeagnus pungens thumb }\end{array}$ \\
\hline Expo Park & 5 & - & Loquat, Cedar, Hu shaddock, Lawn \\
\hline Century Park & 9 & $\begin{array}{c}0-27 \mathrm{~cm} \text { (developed root system ) } \\
27-39 \mathrm{~cm} \text { (lots of roots) } \\
39-78 \mathrm{~cm} \text { (a few roots and dead roots) }\end{array}$ & $\begin{array}{l}\text { Camellia sasanqua, Buxus sinica, Acer } \\
\text { palmatum, Slash pine, Mei flower tree }\end{array}$ \\
\hline Chenshan Botanical Garden & 4 & - & $\begin{array}{l}\text { Crabapple tree, Photinia, } \\
\text { Rosa chinensis, Hemerocallis }\end{array}$ \\
\hline
\end{tabular}

Note: “-” represent that soil profile that was harvested.

in clean polyethylene bags for the determination of soil OM and TN. The 2-mm soil samples were used for the saturated extraction and the determination of elements extracted by AB-DTPA (ammonium bicarbonate-diethylenetriamine pentaacetic acid) method [10]. AB-DTPA is a common "universal soil extractant" and is also used to evaluate the bio-availability of non-essential heavy metals. It is a gentle extractant used to mimic the ability of roots to assimilate minerals.

Soil water content was determined gravimetrically after heating in an oven at $105^{\circ} \mathrm{C}$ for 8 h; all results are presented on an oven dry basis. Soil OM was determined using the potassium dichromate oxidation procedure [11]. AB-DTPA extraction was employed to determine the bio-available concentrations of elements $\mathrm{K}, \mathrm{Cu}, \mathrm{Fe}$, Mn, Zn, Mg, S, Na and P. The analytical determinations in the extracts were made via optical emission spectroscopy using Inductively Coupled Plasma. Soil pH, EC and water extractable chlorine were measured by the saturated extraction method [10]. This method gives the best true estimate of dissolved salts in soil moisture. Soil $\mathrm{pH}$ was determined directly on the paste with a $\mathrm{pH}$ meter. Soil EC and chlorine were estimated by extracting the liquid phase of the saturation paste under partial vacuum. Soil EC was measured with conductivity meter and chlorine by ion chromatography.

\subsection{Quality Control}

The quality of chemical analysis was validated by repeated measurements of blanks and reference samples. Chemical analyses were repeated until a precision of $\pm 5 \%$ and an accuracy of $95 \%$ - $105 \%$ was achieved; while prepared blanks were always below instrumental detection limits.

\section{Results and Discussion}

\subsection{Horizontal Distribution of Soil Properties of Urban Parks}

Soil properties of the four urban parks are presented in Table 2. The soil pH in the different parks was relatively consistent, with mean $\mathrm{pH}$ of soils from Zhongshan Park, Expo Park, Century Park and Chenshan Botanical Garden being 7.4, 7.7, 7.5 and 7.6, respectively. Moreover, the coefficients of variation (CVs) of soil pH from the different parks were $<5.7 \%$, and therefore slightly alkaline might be the main characteristic of urban park soils in Shanghai, in close agreement with the results of Yang et al. [12]. Previous studies also revealed that the urban soils had a higher $\mathrm{pH}$ [13], with extraneous materials such as bricks and stones included in the soils the primary causative factor [14].

EC of soils reflects the concentrations of dissolved salts in soil moisture. The EC value of soil samples collected were within the range of 0.3 - 3.3 with an average of $1.0 \pm 1.3 \mathrm{mS} / \mathrm{cm}$ for Zhongshan Park, 0.9 - 1.6 with average of $1.2 \pm 0.3 \mathrm{mS} / \mathrm{cm}$ for Expo Park, 0.4 - 1.9 with average of $0.9 \pm 0.6 \mathrm{mS} / \mathrm{cm}$ for Century Park and 1.1 2.8 with average of $1.9 \pm 0.8 \mathrm{mS} / \mathrm{cm}$ for Chenshan Botanical Garden (Table 2). According to the classification system established by Richards summarized (Table 2s-1) [15], sensitive crops (e.g. bean) can only be grown without yield loss in soils with EC $<2 \mathrm{mS} / \mathrm{cm}$, and so EC value of all soils from Expo Park and Century Park met the standard for sensitive plant growth. However, 20.1\% of EC values for soil samples from Zhongshan 
Table 2. Properties of soils collected from Zhongshan Park, Expo Park, Century Park and Chenshan Botanical Garden.

\begin{tabular}{|c|c|c|c|c|c|c|c|c|c|c|}
\hline \multirow{2}{*}{ Parameter } & \multicolumn{5}{|c|}{ Zhongshan Park (n = 9) } & \multicolumn{5}{|c|}{ Expo Park $(\mathrm{n}=5)$} \\
\hline & Mean & Min & Max & SD & CV (\%) & Mean & Min & Max & SD & CV (\%) \\
\hline $\mathrm{pH}$ & 7.4 & 7.0 & 7.8 & 0.4 & 5.7 & 7.7 & 7.3 & 8.0 & 0.3 & 3.9 \\
\hline $\mathrm{EC}(\mathrm{mS} / \mathrm{cm})$ & 1.0 & 0.3 & 3.3 & 1.3 & 120.6 & 1.2 & 0.9 & 1.6 & 0.3 & 25.7 \\
\hline $\mathrm{Cl}(\mathrm{mg} / \mathrm{L})$ & 126.4 & 7.0 & 536.0 & 229.3 & 181.4 & 132.0 & 98.0 & 172.0 & 33.8 & 25.6 \\
\hline Organic matter (g/kg) & 31.7 & 16.0 & 45.1 & 13.5 & 42.5 & 18.8 & 8.4 & 29.0 & 9.4 & 49.9 \\
\hline Total nitrogen (g/kg) & 1.5 & 0.9 & 2.1 & 0.6 & 38.0 & 0.9 & 0.4 & 1.3 & 0.4 & 50.8 \\
\hline Available P (mg/kg) & 5.8 & 1.7 & 11.4 & 3.8 & 65.1 & 24.0 & 13.4 & 51.2 & 18.2 & 75.9 \\
\hline Available K (mg/kg) & 177.3 & 110.6 & 323.5 & 85.4 & 48.1 & 211.4 & 68.0 & 378.9 & 130.5 & 61.7 \\
\hline Available Fe (mg/kg) & 47.7 & 28.6 & 81.3 & 21.2 & 44.4 & 62.8 & 43.5 & 79.0 & 16.7 & 26.6 \\
\hline Available Mn (mg/kg) & 2.2 & 1.8 & 2.5 & 0.3 & 13.2 & 3.3 & 2.9 & 3.7 & 0.4 & 11.4 \\
\hline Available Zn (mg/kg) & 21.5 & 7.9 & 32.6 & 12.2 & 56.5 & 7.3 & 4.1 & 9.8 & 2.5 & 34.0 \\
\hline Available Cu (mg/kg) & 11.4 & 4.6 & 18.4 & 6.5 & 57.1 & 3.5 & 0.8 & 6.0 & 2.1 & 61.3 \\
\hline Available Mg (mg/kg) & 194.3 & 101.6 & 271.5 & 77.5 & 39.9 & 156.8 & 51.4 & 248.7 & 101.4 & 64.7 \\
\hline Available Na (mg/kg) & 26.1 & 10.8 & 64.0 & 21.6 & 82.9 & 97.0 & 75.9 & 141.5 & 30.9 & 31.8 \\
\hline Available S (mg/kg) & 35.3 & 7.2 & 105.0 & 39.8 & 112.7 & 62.0 & 34.8 & 101.7 & 29.9 & 48.2 \\
\hline \multirow{2}{*}{ Parameter } & \multicolumn{5}{|c|}{ Century Park (n = 9) } & \multicolumn{5}{|c|}{ Chenshan Botanical Garden $(n=4)$} \\
\hline & Mean & Min & Max & SD & CV (\%) & Mean & Min & Max & SD & CV (\%) \\
\hline $\mathrm{pH}$ & 7.5 & 7.2 & 7.7 & 0.2 & 2.0 & 7.6 & 7.2 & 7.9 & 0.3 & 3.4 \\
\hline $\mathrm{EC}(\mathrm{mS} / \mathrm{cm})$ & 0.9 & 0.4 & 1.9 & 0.6 & 63.2 & 1.9 & 1.1 & 2.8 & 0.8 & 42.5 \\
\hline $\mathrm{Cl}(\mathrm{mg} / \mathrm{L})$ & 135.0 & 21.0 & 571.0 & 198.5 & 147.1 & 119.4 & 67.0 & 190.0 & 51.9 & 43.5 \\
\hline Organic matter (g/kg) & 33.0 & 13.9 & 71.2 & 21.4 & 65.0 & 42.7 & 18.5 & 102.6 & 34.2 & 80.0 \\
\hline Total nitrogen (g/kg) & 1.8 & 0.9 & 3.0 & 0.8 & 44.8 & 2.3 & 1.1 & 5.5 & 1.8 & 79.7 \\
\hline Available P (mg/kg) & 56.0 & 2.7 & 186.3 & 68.8 & 122.8 & 64.6 & 33.4 & 151.4 & 49.0 & 75.9 \\
\hline Available K (mg/kg) & 347.2 & 170.8 & 788.9 & 224.9 & 64.8 & 426.2 & 330.6 & 543.3 & 88.4 & 20.7 \\
\hline Available Fe (mg/kg) & 39.5 & 27.3 & 66.0 & 13.4 & 34.0 & 152.4 & 82.8 & 299.5 & 90.3 & 59.2 \\
\hline Available Mn (mg/kg) & 4.6 & 1.4 & 14.5 & 4.6 & 99.5 & 5.2 & 1.9 & 10.5 & 4.0 & 77.0 \\
\hline Available Zn (mg/kg) & 12.3 & 3.1 & 34.5 & 11.3 & 91.9 & 6.7 & 2.6 & 11.9 & 3.4 & 50.0 \\
\hline Available Cu (mg/kg) & 5.2 & 3.0 & 10.2 & 2.5 & 47.8 & 9.1 & 4.2 & 16.1 & 4.6 & 50.1 \\
\hline Available Mg (mg/kg) & 189.6 & 103.4 & 271.5 & 54.9 & 29.0 & 320.4 & 205.1 & 407.0 & 74.2 & 23.2 \\
\hline Available Na (mg/kg) & 59.5 & 13.5 & 233.1 & 79.1 & 132.9 & 109.4 & 42.1 & 184.1 & 55.5 & 50.8 \\
\hline Available S (mg/kg) & 60.6 & 12.7 & 159.0 & 52.4 & 86.4 & 212.2 & 70.7 & 528.0 & 190.5 & 89.8 \\
\hline
\end{tabular}

Park were in the range that adversely affects growth of moderately saline-sensitive plants (2 - $4 \mathrm{mS} / \mathrm{cm})$. Of samples from Chenshan Botanical Garden, 40.5\% had salinity that exceeded the standard for growth of saline-sensitive plants but met the standard for moderately sensitive plants. Moreover, the CV of EC varied greatly among the parks, indicating heterogeneities of soil [1]. Therefore, plant species should be selected based on soil properties, especially when large amounts of green space areas are constructed. 
As the vital aggregating agent, soil OM can influence soil structural formation and maintenance. The amount of soil OM differed among the four parks (Table 2), with mean contents in the following order: Chenshan Botanical Garden $>$ Century Park $\approx$ Zhongshan Park $>$ Expo Park. Compared with the Chinese soil fertility classes (Table 2s-2), 23.8\% of soil OM contents from the parks were considered extremely high, 19.0\% were high, $23.8 \%$ were moderate to high, $28.6 \%$ were low to moderate and $4.8 \%$ were low. This was similar to a previous study [16]. Although green space soils are covered by vegetation, which would be expected to accumulate OM, management practices such as clearing leaves can lower soil OM contents, a consequence of which is disappearance of fertile topsoil to keep it "neat".

For TN, $28.6 \%$ of soil samples were extremely high, $19.0 \%$ were high, $33.3 \%$ were moderate to high, $9.5 \%$ were low to moderate, $4.8 \%$ were low and $4.8 \%$ were extremely low. The TN contents of soils were significantly correlated with OM, consistent with results of Jim [3] and Yang et al. [12].

As the two major macro-nutrients for plants, levels of $\mathrm{P}$ and $\mathrm{K}$ should be studied. The contents of available $\mathrm{P}$ and available $\mathrm{K}$ in soils were near to those of earlier reports that showed $\mathrm{K}$ was more abundant in soil than $\mathrm{P}$ [17]. The available Fe, Mn, $\mathrm{Zn}$ and $\mathrm{Cu}$ of all soil samples were high compared with the established criteria of Soltanpour (Table 2s-3) for which growth is expected to be within $90 \%$ of the optimum rate for each nutrient [18]. Thus these parks had sufficient micro-nutrients $\mathrm{Fe}, \mathrm{Cu}, \mathrm{Zn}$ and $\mathrm{Mn}$ for plant growth. This may be due to the alluvial soil, which is the main soil type in Shanghai. In addition, the urban soil contamination may also result in increasing of soil $\mathrm{Zn}$ and $\mathrm{Cu}$ contents. The bio-available concentrations of Fe and Mn increase in soil that is poorly aerated promoting the reduction of Fe and $\mathrm{Mn}$.

The contents of available $\mathrm{Na}$ and $\mathrm{S}$ also had a large range in CV. Available Na ranged from 10.8 (Zhongshan Park) to $233.1 \mathrm{mg} / \mathrm{kg}$ (Century Park), and available S from 7.2 (Zhongshan Park) to $528.0 \mathrm{mg} / \mathrm{kg}$ (Chenshan Botanical Garden). The contents of available Na and S in surface soil decreased with the increasing age of parks, which may be ascribed to leaching and application of fertilizer, and this hypothesis will be further tested in following studies.

\subsection{Vertical Distribution of Soil Properties of Urban Parks}

Generally speaking, the mechanisms affecting the vertical distribution of soil nutrients can be classified into at least four major processes: weathering, atmospheric deposition, leaching and biological cycling [19]. Because the effects of plant roots on biological cycling of soil nutrients are large, therefore sampling layers should be defined according to the distribution of plant roots in the sampling position. The vertical distribution of soil nutrients in different distribution layers of plant roots for Zhongshan Park and Century Park are presented in Figure 1. $\mathrm{pH}$ and EC values were clearly enhanced with increased soil depth and OM and TN contents decreased-possibly due to leaching and biological cycling. Leaching moves salt ions downward and increases salinity with increasing soil depth but, in contrast, plant litterfall and application of organic fertilizer or organic modified materials on the soil surface can lead to a shallower distribution of OM and TN. Many studies have reported significant positive correlations between TN and OM contents [12]. This is expected since mature OM generally contains about $5 \% \mathrm{~N}$.

CI is an easily mobile element in soil and is not likely to constrain plant growth with adequate leaching [20]. This phenomenon was also supported in the present study (Figure 1), which showed CI concentrations increased with soil depth. Phillips [21] and Tyler et al. [22] also considered that CI concentrations were associated with the soil depth.

Contents of $\mathrm{P}$ and $\mathrm{K}$ tended to decrease with increased soil depth, which differed to CI, and might be ascribed to the plant cycling and management practices. $\mathrm{P}$ and $\mathrm{K}$ are not readily mobile in soil and generally remain in the soil profile to which they have been applied. On one hand, it may be generally recognized that $\mathrm{P}$ and $\mathrm{K}$ are the main nutrients limiting plant growth, and have shallower distributions than nutrients that are less limiting [23]. On the other hand, organic fertilizer or organic modified materials with higher P and K are usually applied to surface soil of green spaces instead of the whole soil profile.

$\mathrm{Fe}, \mathrm{Mn}, \mathrm{Cu}$ and $\mathrm{Zn}$ are essential micro-nutrients for plant growth and important for gene expression and biosynthesis of proteins [24] [25]. Available Fe, Mn, Cu and Zn contents tended to decrease with increasing soil depth, which might be controlled by plant cycling and soil pH [23] [25]. Generally, root distribution and maximum rooting depth play an important role in shaping micro-nutrient profiles [23] [26], because some nutrients absorbed by plants are transported aboveground and recycled to the soil surface by litterfall [27]. Furthermore, 

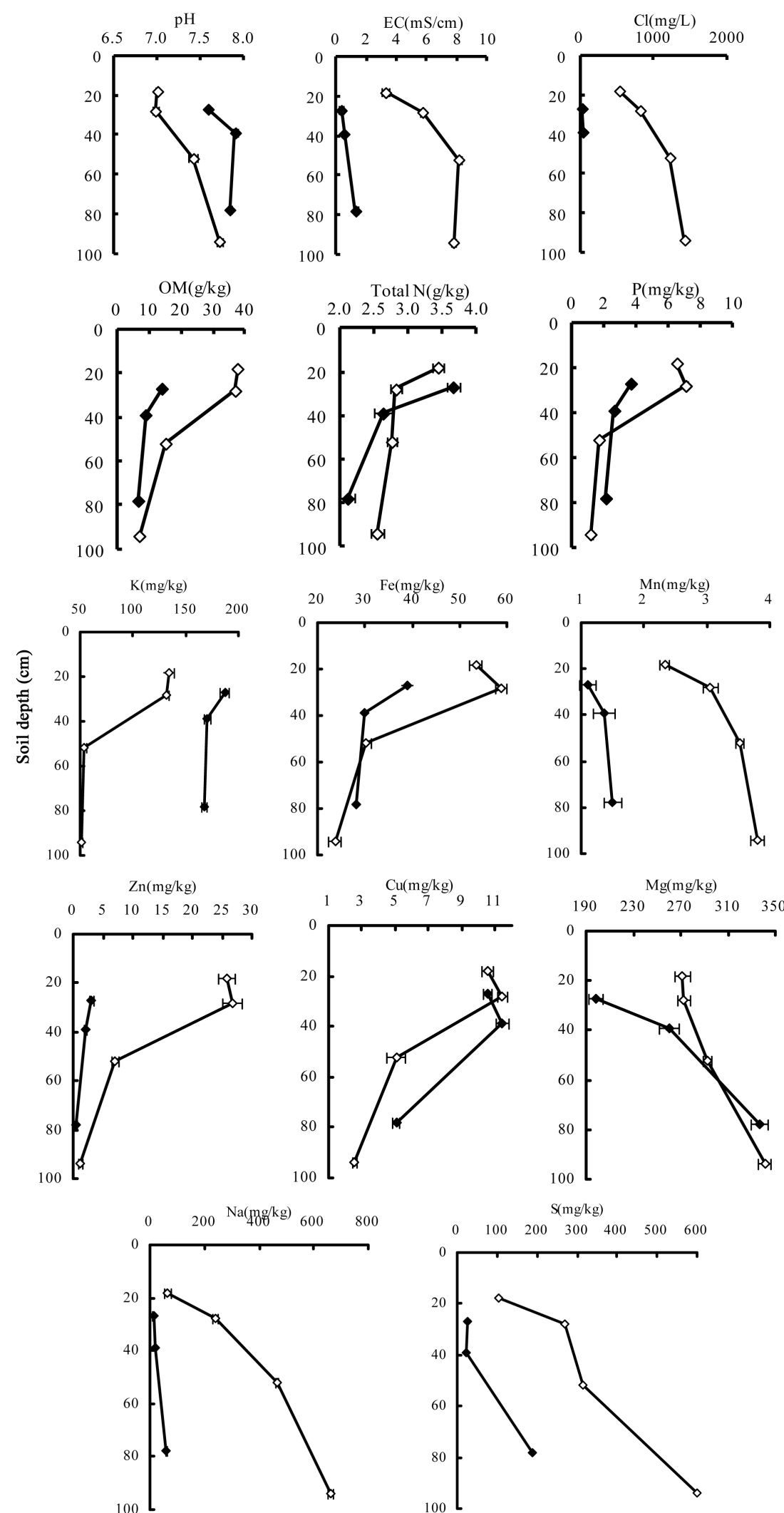

Figure 1. Vertical distribution of soil nutrients in different layers of plant roots. (The hollow points represent Zhongshan park, and the solid points represent Century Park). 
$\mathrm{Fe}, \mathrm{Mn}, \mathrm{Cu}$ and $\mathrm{Zn}$ are the most bio-available at lower $\mathrm{pH}$, and their cationic forms may be changed to insoluble forms such as hydroxides and oxides in less acidic soil [28]. Therefore, increasing $\mathrm{pH}$ with soil depth may be another reason for the lower contents of these micro-nutrients in deeper soil. Another cause of soil acidification is application of fertilizers, and these are applied to the soil surface [29].

The levels of Mg, Na and S tended to be low in the soil surface, which was in contrast with all other elements. Previous studies indicated that nutrients that are rarely required by plants (such as Na) have shallower distributions in soils [17]. Furthermore, the role of leaching is probably important for available $\mathrm{Mg}, \mathrm{Na}$ and $\mathrm{S}$ because their contents had an increasing trend with soil depth [23].

\subsection{Relationship among Soil Chemical Properties}

The relationships between nutrient elements and soil properties were studied, and the results are presented in Table 3. $\mathrm{pH}$ values were significantly negatively correlated with $\mathrm{OM}, \mathrm{TN}$ and available $\mathrm{Zn}$ and $\mathrm{Cu}$. The contents of $\mathrm{OM}, \mathrm{TN}$ and available $\mathrm{Cu}$ and $\mathrm{Zn}$ decreased dramatically with increasing depth, while $\mathrm{pH}$ increased, which might be related to OM, organic residues, applying of organic modified materials and exudation of plant roots [26]. There were also significant positive correlations between $\mathrm{OM}$ and $\mathrm{TN}$, available $\mathrm{P}$, available $\mathrm{K}$, available Mn, available $\mathrm{Zn}$ and available $\mathrm{Mg}$, which indicated the roles of plant cycling. Nutrients taken up by deep roots would be transported to the soil surface, especially for plants with deeper roots [30].

EC values were positively and significantly correlated with the content of chlorine and available Mg and S; moreover, the chlorine concentration was positively correlated with available K, Mn, Zn and Na (Table 3). These results suggested that there was a significant effect of leaching on vertical distribution of soil nutrient elements, which would deplete them from the topsoil, and accumulate them in deeper layers and produce a peak at the maximum rooting depth [22].

\section{Conclusions}

Urban ecological environments can have a large impact on sustainable economic development, and can be influenced to a large extent by the amount of green space available to the public. Growth of vegetation also has a useful ecological function and is strongly affected by soil quality. Therefore, it is essential that the content of various nutrient elements in soils of green spaces are investigated. The horizontal and vertical distributions of

Table 3. Pearson's correlation coefficients among soil nutrient elements and soil properties.

\begin{tabular}{|c|c|c|c|c|c|c|c|c|c|c|c|c|c|c|}
\hline Parameters & $\mathrm{pH}$ & EC & Chlorine & $\mathrm{OM}$ & $\mathrm{TN}$ & $\mathrm{P}$ & K & $\mathrm{Fe}$ & Mn & $\mathrm{Zn}$ & $\mathrm{Cu}$ & $\mathrm{Mg}$ & $\mathrm{Na}$ & S \\
\hline $\mathrm{pH}$ & 1 & -0.398 & -0.324 & $-0.534^{*}$ & $-0.503^{*}$ & -0.060 & -0.095 & 0.133 & -0.058 & $-0.652^{* *}$ & $-0.513^{*}$ & -0.241 & 0.259 & 0.028 \\
\hline EC & & 1 & $0.462^{*}$ & 0.382 & 0.391 & -0.074 & 0.150 & 0.327 & 0.082 & -0.070 & 0.161 & $0.488^{*}$ & 0.196 & $0.507^{*}$ \\
\hline $\mathrm{Cl}$ & & & 1 & 0.429 & 0.280 & 0.427 & $0.449^{*}$ & -0.028 & $0.520^{*}$ & $0.476^{*}$ & 0.056 & 0.210 & $0.610^{* *}$ & 0.319 \\
\hline $\mathrm{OM}$ & & & & 1 & $0.972^{* *}$ & $0.438^{*}$ & $0.708^{* *}$ & 0.023 & $0.555^{* *}$ & $0.510^{*}$ & 0.306 & $0.627^{* *}$ & 0.183 & 0.109 \\
\hline $\mathrm{TN}$ & & & & & 1 & 0.351 & $0.676^{* *}$ & 0.011 & $0.490^{*}$ & 0.372 & 0.261 & $0.630^{* *}$ & 0.076 & 0.105 \\
\hline $\mathrm{P}$ & & & & & & 1 & $0.782^{* *}$ & 0.097 & $0.569^{* *}$ & 0.285 & 0.000 & 0.311 & $0.561^{* *}$ & 0.176 \\
\hline K & & & & & & & 1 & 0.207 & $0.668^{* *}$ & 0.280 & 0.152 & $0.547^{*}$ & $0.626^{* *}$ & 0.368 \\
\hline $\mathrm{Fe}$ & & & & & & & & 1 & 0.335 & -0.184 & 0.400 & 0.347 & 0.338 & $0.693^{* *}$ \\
\hline Mn & & & & & & & & & 1 & 0.282 & 0.008 & 0.138 & $0.517^{*}$ & 0.257 \\
\hline $\mathrm{Zn}$ & & & & & & & & & & 1 & $0.625^{* *}$ & 0.143 & 0.059 & -0.101 \\
\hline $\mathrm{Cu}$ & & & & & & & & & & & 1 & 0.411 & -0.040 & 0.393 \\
\hline $\mathrm{Mg}$ & & & & & & & & & & & & 1 & 0.311 & 0.362 \\
\hline $\mathrm{Na}$ & & & & & & & & & & & & & 1 & $0.558^{* *}$ \\
\hline$S$ & & & & & & & & & & & & & & 1 \\
\hline
\end{tabular}


soil nutrients in Zhongshan Park, EXPO Park, Century Park and Chenshan Botanical Garden in Shanghai confirmed that urban soils had a heterogeneous spatial distribution. The CVs of various soil qualities except for $\mathrm{pH}$ varied greatly between and even within parks. For example, the mean $\mathrm{pH}$ of soils from Zhongshan Park, Expo Park, Century Park and Chenshan Botanical Garden was 7.4, 7.7, 7.5 and 7.6, respectively, and the CVs of soil $\mathrm{pH}$ from different parks was $<5.7 \%$, indicating a slightly alkaline nature of these urban park soils. $\mathrm{pH}$ and EC values increased with increasing soil depth likely due to leaching, and nutrients limiting for plants (such as $\mathrm{N}, \mathrm{P}$, $\mathrm{K}, \mathrm{Fe}, \mathrm{Cu}$ and $\mathrm{Zn}$ ) had more shallow distributions due to absorption by plant roots. However, $\mathrm{Mg}, \mathrm{Na}, \mathrm{S}$ and chlorine decreased possibly due to the contribution of leaching and bio-cycling.

\section{Acknowledgements}

We thank the special program of Shanghai Landscaping Administration Bureau (Project G102402) for financial support.

\section{Conflict of Interest}

The authors declare none.

\section{References}

[1] Gyekye, K.A. (2013) Chemical Characteristics of Urban Soils of Vasileostrovsky Ostrov and Elagin Ostrov, St Petersburg, Russia. West African of Applied Ecology, 21, 121-133.

[2] Lu, Y.H. (2005) Soil Fertility Assessment and Managing Measures for Urban Green Space in Shenzhen City. Journal of Soil and Water Conservation, 19, 153-156 (in Chinese).

[3] Jim, C.Y. (1998) Urban Soil Characteristics and Limitations for Landscape Planting in Hong Kong. Landscape Urban Plan, 40, 235-249. http://dx.doi.org/10.1016/S0169-2046(97)00117-5

[4] Bian, Z.X. and Wang, Q.B. (2003) Study on Urban Park Soil Nutrients in Shenyang City’s Green Areas. Chinese Journal of Soil Science, 34, 284-290 (in Chinese).

[5] Chen, X. and Bao, B. (2008) The Main Problem and Improvement Measures of Green Space Soils in Downtown Area of Chongqing City. Modern Agricultural Sciences and Technology, 23, 58-59 (in Chinese).

[6] Nazif, W., Perveen, S. and Saleem, I. (2006) Status of Micronutrients in Soils of District Bhimber (Azad Jammu and Kashmir). Journal of Agricultural and Biological Science, 1, 35-40.

[7] Omonode, R.A. and Vyn, T.J. (2006) Vertical Distribution of Soil Organic Carbon and Nitrogen under Warm-Season Native Grasses Relative to Croplands in West-Central Indiana, USA. Agriculture, Ecosystems and Environment, 117, 159-170. http://dx.doi.org/10.1016/j.agee.2006.03.031

[8] Meng, Y.J., Ma, X., Chen, D., Wu, P. and Chen, M. (2010) MicroRNA-Mediated Signaling Involved in Plant Root Development. Biochemical and Biophysical Research Communications, 393, 345-349. http://dx.doi.org/10.1016/j.bbrc.2010.01.129

[9] Guérif, J., Richard, G. and Dürr, C. (2001) A Review of Tillage Effects on Crop Residue Management, Seedbed Conditions, and Seedling Establishment. Soil \& Tillage Research, 61, 13-32. http://dx.doi.org/10.1016/S0167-1987(01)00187-8

[10] LY/T 2445-2015 (2015) Technical Specification for the Protection of Greening Topsoil (in Chinese).

[11] Lu, C.H. (2000) Analytical Methods for Soils and Agricultural Chemistry. Scientific and Technology Press, Beijing. (In Chinese)

[12] Yang, L.Y., Li, Y. and Peng, K. (2014) Nutrients and Heavy Metals in Urban Soils under Different Green Space Types in Anji, China. Catena, 115, 39-46. http://dx.doi.org/10.1016/j.catena.2013.11.008

[13] Fang, H.L., Chen, L., Huang, Y.Z., Zhang, Q., Xi, Y.W. and Zhao, X.Y. (2007) Current Situation and Strategy for the Soil Quality of Newly-Established Green Belts in Shanghai. Scientia Silvae Sinicae, 43, 89-94. (In Chinese)

[14] Alexandrovskaya, E.I. and Alexandrovskiy, A.L. (2000) History of the Cultural Layer in Moscow and Accumulation of Anthropogenic Substances in It. Catena, 41, 249-259. http://dx.doi.org/10.1016/S0341-8162(00)00107-7

[15] Richard, L.A., Ed. (1954) Diagnosis and Improvement of Saline and Alkali Soils. USDA Agriculture Handbook No. 60, US Government Printing Office, Washington DC.

[16] Biasioli, M., Barberia, R. and Ajmonemarsan, F. (2006) The Influence of a Large City on Some Soil Properties and Metals Content. Science of the Total Environment, 356, 154-164. http://dx.doi.org/10.1016/j.scitotenv.2005.04.033 
[17] Thompson, K., Parkinson, J.A. and Band, S.R. (1997) A Comparative Study of Leaf Nutrient Concentration in a Regional Herbaceous Flora. New Phytologist, 136, 679-689. http://dx.doi.org/10.1046/j.1469-8137.1997.00787.x

[18] Soltanpour, P.N. (1985) Use of AB-DTPA Soil Test to Evaluate Element Availability and Toxicity. Communication in Soil Science and Plant Analysis, 16, 323-338. http://dx.doi.org/10.1080/00103628509367607

[19] Trudgill, S.T. (1988) Soil and Vegetation Systems. Oxford University Press, New York.

[20] Yaalon, D.H. (1965) Downward Movement and Distribution of Anions in Soil Profiles with Limited Wetting. In: Hallsworth, E.G. and Crawford, D.V., Eds., Experimental Pedology, Butterworths, London, 157-164.

[21] Phillips, F.M. (1994) Environmental Tracers for Water Movement in Desert Soils of the American Southwest. Soil Science Society of America Journal, 58, 15-24. http://dx.doi.org/10.2136/sssaj1994.03615995005800010003x

[22] Tyler, S.W. and Walker, G.R. (1994) Root Zone Effects on Tracer Migration in Arid Zones. Soil Science Society of America Journal, 58, 25-31. http://dx.doi.org/10.2136/sssaj1994.03615995005800010004x

[23] Jobbáge, E.G. and Jackson, R.B. (2001) The Distribution of Soil Nutrients with Depth: Global Patterns and the Imprint of Plants. Biogeochemistry, 53, 51-77. http://dx.doi.org/10.1023/A:1010760720215

[24] Rengel, Z. (2003) Heavy Metals as Essential Nutrients. In: Prasad, M.N.V. and Hagemeyer, J., Eds., Heavy Metal Stress in Plants: Molecules to Ecosystems, Springer-Verlag, Berlin, Heidelberg, 271-294.

[25] Gao, S., Yang, W., Wang, S. and Chen, F. (2008b) Effects of Copper an Growth, Antioxidant Enzymes and Phenylalanine Ammonia-Lyase Activities in Jatropha curcas L. Seedling. Plant, Soil and Environment, 54, 117-122.

[26] Jiang, Y., Zhang, Y.G., Liang, W.J. and Wen, D.Z. (2005) Profile Distribution of Micronutrients in an Aquic Brown Soil as Affected by Land Use. Agricultural Sciences in China, 4, 199-206.

[27] Stark, J.M. (1994) Causes of Soil Nutrient Heterogeneity at Different Scales. In: Caldwell, M.M. and Pearcy, R.W., Eds., Exploitation of Environmental Heterogeneity by Plants, Academic Press, San Diego, 255-284. http://dx.doi.org/10.1016/B978-0-12-155070-7.50014-7

[28] Brady, N.C. and Weil, R.R. (2002) The Nature and Properties of Soils. 13th Edition, Prentice Hall, Upper Saddle River.

[29] Wallace, A. (1994) Soil Acidification from Use of Too Much Fertilizer. Communications in Soil Science and Plant Analysis, 25, 87-92. http://dx.doi.org/10.1080/00103629409369010

[30] Rengel, Z. (2007) Cycling of Micronutrients in Terrestrial Ecosystems. In: Marschner, P. and Rengel, Z., Eds., Nutrient Cycling in Terrestrial Ecosystems, Springer-Verlag, Berlin, Heidelberg, 93-121. http://dx.doi.org/10.1007/978-3-540-68027-7_4 


\section{Appendix}

Table 2s-1. Salinity classes for soils.

\begin{tabular}{cccc}
\hline USDA class & Electrical conductivity range $(\mathrm{mS} / \mathrm{cm})$ & Crop salt tolerance & Example Crop \\
\hline A & $0-2$ & Sensitive & Bean, strawberry, carrot, onion, citrus \\
B & $2-4$ & Moderately sensitive & Corn, cucumber, tomato \\
C & $4-8$ & Moderately tolerant & Wheat \\
D & $8-16$ & Tolerant & Barley \\
\hline
\end{tabular}

Table 2s-2. General soil fertility ratings ( $\mathrm{g} / \mathrm{kg}$ ).

\begin{tabular}{ccccccc}
\hline Class & Extremely high & High & Moderate to high & Low to moderate & Low & Extremely low \\
\hline Organic matter & $>40$ & $30-40$ & $20-30$ & $10-20$ & $6-10$ & $<6$ \\
Total nitrogen & $>2$ & $1.5-2$ & $1-1.5$ & $0.75-1$ & $0.5-0.75$ & $<0.5$ \\
\hline
\end{tabular}

Table 2s-3. Critical soil test values of AB-DTPA extractable copper, iron, manganese and zinc by Soltanpour (1985).

\begin{tabular}{cccc}
\hline Micro-nutrients & & Content $(\mathrm{mg} / \mathrm{kg})$ & Medium \\
\cline { 2 - 4 } Iron & Low & $3.0-5.0$ & $>5.0$ \\
Copper & $<3.0$ & $0.3-0.5$ & $>0.5$ \\
Zinc & $<0.3$ & $0.9-1.5$ & $>1.5$ \\
Manganese & $<0.9$ & $0.6-1.0$ & $>1.0$ \\
\hline
\end{tabular}

